\title{
The Literature of Participation: From Optimism to Realism
}

\begin{abstract}
Likert, whose New Patterns of Management appeared in 1961, saw participation as a remedy for those twin ailments suffered by employees in hierarchical organizations: poor performance and tensions. Less optimistic have been recent writers on management. The conditions that facilitate better performance and fewer tensions are not fully understood. Often, there is no positive relationship between job satisfaction and improved performance. And for those who are invited to participate but do not wish to, participation can be a source of tension.
\end{abstract}

$\mathrm{T}$ MANAGEMENT is enormous, consisting mainly of reports of experiments and observations made by social scientists in complex organizations. Only a few examples of this literature are cited in this essay, with emphasis on those that illustrate my thesis. (The literature discussed is listed in a bibliography at the end of this article.)

Most of these studies have been conducted in organizations other than libraries, yet all have relevance for librarians because complex organizations have much in common: their structure is hierarchical; they tend to adopt bureaucratic practices, such as the writing down of regulations; they employ an advanced technology, such as the use of computers and other mechanized equipment; and many of those employed in the organization are specialists.

The thesis of this essay is that the optimism with respect to participation that marked Likert's New Patterns of

Louis Kaplan is professor in the Library School, University of Wisconsin-Madison.
Management ${ }^{1}$ has been succeeded by a more realistic outlook. This greater realism stems from at least three factors: theoretical formulations have come under suspicion or have had to be rejected; more variables are receiving consideration than when Likert wrote his book; and there is fear on the part of some social scientists that they have been working with imprecise definitions and unreliable instruments of measurement. $^{2}$

Despite the new realism, participation remains an important tool of management. Though participation is easily misunderstood, is costly to introduce properly, and sometimes has led to expectations that cannot be met, its use by management in the United States (and elsewhere) has grown; in fact, to a large number of managers participation is old hat, except that management's understanding of participation is seldom the same as Likert's. This is not surprising, because there are various answers to the question Who participates and when?

Likert recognized only two styles of management, namely, "authoritative" 
and "participative." Included in the former was the "consultative," even though Likert admitted that there was in this style "quite a bit" of "interaction and communication," and that "specific decisions at lower levels" were permitted. ${ }^{3} \mathrm{He}$ believed that management should be dyadic; that is, management and its employees should share decision making in approximately equal amounts. Management in these circumstances would not need to use its veto power. Delegation of decision making (which is nondyadic) would not be practiced.

Likert chose to omit discussion of individual personality differences, even though these differences largely determine whether an employee will accept or reject the offer of participation; only a few years later, Vroom demonstrated the importance of personality in his widely acclaimed book, Work and Motivation. ${ }^{4}$ Nor did Likert concern himself with organizational variables (such as the state of technology), to which much attention has been given in recent years. As for Likert's "either or" view of management style, many writers now believe that there is no one best style of management for every situation.

\section{What Is Participation?}

Participation can be conceived as a process in which power or influence is shared. This is accomplished mainly through the making of decisions in which various levels of management and employees engage. When participation is so viewed, management has alternatives beyond the democratic and the autocratic; rather, there is available to it a continuum of alternatives lying within the two managerial styles. Among the alternatives that can be viewed as participative, there is delegation. Another is consultation, which sometimes takes the form of seeking recommendations. With delegation and consultation the degree of participation runs high when the veto power is seldom exercised.

Participation and hierarchy are not necessarily hostile. According to one model, the "process shifts the locus of some decisions downward in this dyadic organizational segment, from superior to subordinate." ${ }^{\circ}$ Within hierarchical structures there are considerable differences in morale, rewards, and the growth of individual responsibility. The measurement of these and of related factors leads to the determination of the hierarchical gradient. Two organizations with identical structures can nevertheless be marked by differences in gradient. $^{6}$

Who participates and when is of obvious importance to an understanding of participation. On this point, Follett, who wrote in the 1920s, argued that everybody should take part in decision making, but each according to his capacity. Follett sought to downgrade the hierarchical element by insisting that "authority and responsibility go with function and not with a certain position at the top of the chart." What was desirable, said Follett, was a "diffusion" of authority, but it was not simply a matter of how much control management was willing to surrender; equally important was the extent to which employees could assume responsibility. ${ }^{7}$

Participation is not necessarily tied to hierarchy. Representatives who are elected or appointed may come together to act on organization-wide matters. The same is true of committees that are outside the hierarchy. In either example, we assume that those who act as representatives possess the authority and knowledge to deal with matters appropriate to their purview.

\section{Participation among Managers}

According to Heller, who studied senior managers and the managers who reported directly to them, senior man- 
agers made 36 percent of their decisions unilaterally. If we disregard the Likert model and count all other decisions as participative, including delegation, we come to the conclusion that these 260 managers in fifteen large California firms permitted some degree of sharing in the making of 64 percent of their decisions. However, only 20 percent of their decisions fit the Likert model. With respect to about 50 percent of the decisions, Heller claimed that a "substantial" amount of sharing had been permitted. ${ }^{8}$

What conditions are favorable to sharing? In Heller's view, sharing will be permitted when the skills of the subordinate manager are perceived by the senior as "similar" to his own. The more experienced managers, to Heller's surprise, tend to avoid delegation and unilateral decisions. The more important the decision is to the organization the more likely it is that the senior manager will act unilaterally. Where the "span" of control is great, the senior managers are apt to make unilateral decisions, or to delegate. ${ }^{9}$

Such studies make possible the opinion that "It makes more sense to talk about participative and autocratic situations than it does to talk about participative and autocratic managers." 10 One important "situation" is hierarchical level; according to a study by Blankenship and Miles, 85 percent of high-level managers said they had a considerable degree of autonomy, compared with 38 percent of those in mid-level management and 20 percent of those in the lowest levels of management. ${ }^{11}$

\section{Participation, Job Satisfaction, and Performance}

Because so much has been written about job satisfaction and performance in relation to participation, this discussion must be limited to those authors who have summarized the evidence. The two whose viewpoints are here presented illustrate the contradictory evidence that is encountered. Blumberg, who regards job satisfaction as no less important an outcome than good performance, argues that "There is hardly a study in the entire literature which fails to demonstrate that satisfaction in work is enhanced or that other generally acknowledged beneficial consequences accrue from a genuine increase in workers' decision-making power."12

Lowin, who creates a comprehensive model by which to judge the outcome of participation, and who defines it with care, is more circumspect in his conclusions. Lowin distinguishes between experimental and observational studies within organizations. The former are more meaningful, he argues, and among these he differentiates between the "major" and the "minor." The minor studies, he writes, are reasonably well defined, but methodologically imperfect. Their data are inconclusive. The major studies more nearly meet the prescriptions of the Lowin model, "yet the data are at best suggestive." He concludes with the argument that the effectiveness of participation cannot be ascertained until certain variables (personal and organizational) are further studied. ${ }^{13}$

Job satisfaction, of course, is not solely dependent upon participation, and in any event, those who stress the relationship of participation to job satisfaction, as, for example, Blumberg, are confronted by the evidence that good performance oftentimes is not an outcome of job satisfaction. ${ }^{14}$

\section{On Tensions in Complex Organizations}

Likert said that the outcome of participation would be a "cooperative attitude" marked by "mutual trust and confidence."15 Quite at variance is the view of Presthus, who tells us that the reaction to management, whether it uses sanctions, rewards, or other induce- 
ments, depends largely upon the personality of the individual worker. These he classified as upward-mobiles, ambivalents, and indifferents. "Indifference," says Presthus, "is the typical pattern of accommodation for the majority of organization men." 16 Even when participation is offered by management (see Flener, below), many in the organization will remain aloof.

One source of conflict, of increasing interest to librarians, is collective bargaining. Most who have written on management from the human-relations point of view tend to ignore unions, while proponents of unionism look upon the human-relations school as among the worst enemies of unionism. Thus, Gomberg writes that the "style of permissive management should not be confused with the essence of democracy, the distribution of real power."17 Writing more directly to the point of tension, Barbash sees both participation and unions as merely ameliorative; that is, either may serve as a means of reducing tension, but each brings in its wake still additional sources of strife. To Barbash, tension is inevitable for a number of reasons, among these being the conflict between superiors and subordinates and the envy that arises from differences in skills. ${ }^{18}$

As for professionals in organizations, Blau and Scott have written that the "conflict between bureaucratic and professional orientation is a fundamental issue."19 Etzioni illustrates the conflict by pointing to the damage done to professional work when bureaucracies prevent autonomy. ${ }^{20}$

Apparently, the weight of bureaucracy is heavier on professionals in heteronomous organizations than in the autonomous. In a study by Hall we learn that doctors and lawyers serving in autonomous organizations are freer from authority than are librarians, nurses, and high-school teachers (typical professionals in heteronomous organiza- tions). ${ }^{21}$ Of these three, public librarians experienced the greatest amount of bureaucratic repression.

Not all persons in a particular professional group are anxious to share in decision making. According to Alutto and Belasco, "teachers experiencing decisional saturation tended to be older females teaching at elementary levels in the urban district, perceiving moderate levels of role conflict and possessing moderately unfavorable attitudes towards collective bargaining, strikes and unions." 22

Among the writers who deal with participation in libraries, Marchant claims that one of the advantages of participation is that group decisions "tend to be more readily accepted by the group." 23 A contrary view, not specifically related to libraries, is expressed by Strauss, who cites four possible dysfunctional aspects of decision making by groups: individuals whose opinions have been rejected by the group may be alienated; the expectations aroused by group participation lead to further demands that management cannot always satisfy; the process of group decision making may prove frustrating to several in the group; though participation may bring about group cohesiveness, cohesiveness might be turned against, as well as in favor of, management. ${ }^{24}$

Bundy sees relief from tension through the formation in academic libraries of departments modeled on those found elsewhere in academic institutions. Bundy would have the chief librarian take on the functions of a dean; this would give librarians at some universities more influence in the choice of a chief librarian than they have at present. On the other hand, deans have the kind of authority normally associated with hierarchies. As for the nonprofessional workers, who according to Bundy would remain in a hierarchical status, would these, feeling resentful, organize collective bargaining units?25

Kaser also advises freeing profession- 
als in libraries (though not the nonprofessionals) from the hierarchical structure, but he comes to a structural solution different from Bundy's. Kaser would have the professionals who are not managers come together for the express purpose of making policy; the policy made, the managerial staff would then administer it. ${ }^{26}$ This leaves unanswered the question whether top management can surrender its policy-making responsibility in a heteronomous, service-type agency. And how would this affect the traditional policy-making role of faculty library committees?

While Bundy and Kaser look primarily to the conflicts within libraries, Kaplan considers the conflicts that arise as the result of controls applied by department heads, deans, presidents, and regents. Despite these tension-producing controls, professors do enjoy considerable discretion, mainly because there is general agreement that decisions relating to "academic" affairs ought to be delegated to the faculty. Nevertheless, the act of delegation does not include surrender of veto, though in a certain type of academic institution the veto is seldom employed. ${ }^{27}$ Blau argues that universities are a special kind of bureaucracy rather than a distinct type of organization. ${ }^{28} \mathrm{~A}$ major difference between universities is the amount of sharing permitted in the making of decisions; Kaplan believes that the "participational" climate of a university will have a significant influence on the amount of participation permitted in a library. ${ }^{29}$

Routineness of work is commonly said to be a source of boredom, which in turn could lead to tension. Lynch studied the routineness of work in several functional departments (such as reference, circulation, and cataloging) in three university libraries. In each of the three libraries the greatest amount of routineness was found in the circulation department and the least amount in the reference department. ${ }^{30}$ As part of her investigation of libraries, Lynch advanced the hypothesis "that if the work of the library department varies as to routineness, the amount of discretion available to the worker also would vary in a predictable way." 31 This hypothesis was not validated. What we learn from Lynch (putting aside the tentative nature of her findings) is that routineness is predictable, but the degree of discretion permitted apparently is not.

Discretion, one element of participation, can also be a source of tension. No complex organization can dispense with regulations for the guidance of its employees; yet many employees take advantage of these to avoid making decisions that require the exercise of judgment. That is why decisions that call for the making of exceptions frequently are finally made higher in the hierarchy than where the need for the decision originated. It was this that prompted Truman's remark about the presidency: the buck stops here.

Holley found evidence that "librarians, accustomed to working in a hierarchical structure, are finding it difficult to adjust to a real policy-making role." ${ }^{32}$ Flener, after visiting ten large university libraries, reported that "in most libraries less than 50 percent of the staff seemed interested." ${ }^{33}$ Is it possible that some are indifferent to participation because they view it as one more undesirable feature of complex organizations?

\section{The Demands of Realism}

The assumptions made by managers are critical. One class of assumptions relates to the ability to make decisions. Some managers have confidence in only their own judgment. Others are more likely to seek advice, either because they respect their subordinates or because they do not possess overweening confidence in their own abilities.

Another set of assumptions relates to 
whether individuals can be "happy" in hierarchical organizations. Happiness, one type of manager might argue, is dependent upon the individual's personality and the circumstances in which the individual finds himself outside the organization. Inside the organization, the argument continues, tension is inevitable, worse for some than for others. Other managers will assume that organizational climate is of great importance to happiness; therefore, decision sharing, consideration, and equitable rewards must mark the administration of the organization.

Still another group of assumptions has to do with those in the lower levels of the hierarchy, including the managers. Some top-level managers will assume that these are neither willing nor able to contribute to the goals of the organization. Others will assume the opposite, provided organizational conditions are favorable.

From the viewpoint of realism as it relates to participation, a reasonable set of assumptions might be these. Though tension in complex organizations is inevitable, the amount of tension can be reduced for many persons by reducing the gradient of hierarchy in the organization. One significant method of reducing the gradient is to assume that those who are willing and able to share in decision making ought to be given the opportunity. Those who are given the opportunity must realize that function, knowledge, and decision making must not be separated, and that at the top of the hierarchy in a heteronomous organization responsibility cannot be shifted. Even given these assumptions, no miracles should be expected. Happiness will not be pervasive, nor will there be a necessary improvement in the quality of every decision.

\section{REFERENCES}

1. Rensis Likert, New Patterns of Management (New York: McGraw-Hill, 1961).

$\checkmark 2$. See, for example, Aaron Lowin, "Participative Decision Making: A Model, Literature Critique and Prescription for Research," Organizational Behavior and Human Performance 3:68-106 (1968); and Donald P. Schwab and Larry L. Cummings, "Theories of Performance and Satisfaction: A Review," Industrial Relations 9:408-30 (1972).

3. Likert, New Patterns, p.225, 229.

4. Victor H. Vroom, Work and Motivation (New York: Wiley, 1964), p.183-86.

5. Lowin, "Participative Decision Making," p.69.

6. Arnold S. Tannenbaum and others, Hierarchy in Organizations (San Francisco: Jossey-Bass, 1974).

7. Mary Follett, Dynamic Administration (New York: Harper, 1940), p.213, 153, 109.

8. Frank A. Heller, Managerial Decision Making (London: Tavistock, 1971), p.xvi, 95, 106.

9. Ibid., p.107-8.

10. Victor H. Vroom, "A New Look at Managerial Decision Making," Organizational Dynamics 1:70 (1973).

11. L. V. Blankenship and Raymond E. Miles, "Organizational Structure and Managerial
Decision Behavior," Administrative Science Quarterly 13:114 (1968).

12. Paul Blumberg, Industrial Democracy (New York: Schocken Books, 1969), p.123.

13. Lowin, "Participative Decision Making," p.98-99.

14. Vroom, Work and Motivation, p.175-87.

15. Likert, New Patterns, p.225.

16. Robert V. Presthus, The Organizational Society (New York: Knopf, 1962), p.205.

17. William Gomberg, "The Trouble with Democratic Management," Trans-action 3: 35 (July/Aug. 1966).

18. Jack Barbash, "The Tensions of Work," Dissent 19:240-48 (1972).

19. Peter M. Blau and W. Richard Scott, Formal Organizations (San Francisco: Chandler, 1962), p. 246.

20. Amitai Etzioni, Modern Organizations (Englewood Cliffs, N.J.: Prentice-Hall, 1964), p.76-77.

21. Richard H. Hall, "Some Organizational Considerations in the Professional-Organizational Relationship," Administrative Science Quarterly 12:470-71 (1967).

22. Joseph A. Alutto and James A. Belasco, “A Typology for Participation: Organizational Decision Making," Administrative Science Quarterly 17:123 (1972).

23. Maurice P. Marchant, "Participative Man- 
agement as Related to Personnel Development," Library Trends 20:48 (1971).

24. George Strauss, "Some Notes on Power Equalization," in Harold J. Leavitt, ed., The Social Science of Organizations (Englewood Cliffs, N.J.: Prentice-Hall, 1963), p.70.

25. Mary Lee Bundy, "Conflict in Libraries," College \& Research Libraries 27:260-62 (July 1966).

26. David Kaser, "Modernizing the University Library Structure," College \& Research Libraries 31:229 (July 1970).

27. Louis Kaplan, "Participation: Some Basic Considerations on the Theme of Academe," College \& Research Libraries 34:236-39 (Sept. 1973).
28. Peter M. Blau, Organization of Academic Work (New York: Wiley, 1973).

29. Kaplan, "Participation," p.238.

30. Beverly P. Lynch, "An Empirical Assessment of Perrow's Technology Construct," Administrative Science Quarterly 19:33856 (1974).

31. Beverly P. Lynch, "Organizational Structure and the Academic Library," Illinois Libraries 56:205 (1974).

32. Edward G. Holley, "Organization and Administration of Urban University Libraries," College \& Research Libraries 33: 182 (May 1972).

33. Jane G. Flener, "Staff Participation in Large University Libraries," College \& Research Libraries 34:278 (July 1973).

\section{BIBLIOGRAPHY}

Alutto, Joseph A., and Belasco, James A. "A Typology for Participation: Organizational Decision Making," Administrative Science Quarterly 17:112-25 (1972).

Barbash, Jack. "The Tensions of Work," Dissent 19:240-48 (1972).

Blankenship, L. V., and Miles, Raymond E. "Organizational Structure and Managerial Decision Behavior," Administrative Science Quarterly 13:106-20 (1968).

Blau, Peter M. Organization of Academic Work. New York: Wiley, 1973.

Blau, Peter M., and Scott, W. Richard. Formal Organizations. San Francisco: Chandler, 1962.

Blumberg, Paul. Industrial Democracy. New York: Schocken Books, 1969.

Bundy, Mary Lee. "Conflict in Libraries," College \& Research Libraries 27:253-62 (July 1966).

Etzioni, Amitai. Modern Organizations. Englewood Cliffs, N.J.: Prentice-Hall, 1964.

Flener, Jane G. "Staff Participation in Large University Libraries," College \& Research Libraries 34:275-79 (July 1973).

Follett, Mary. Dynamic Administration. New York: Harper, 1940.

Gomberg, William. "The Trouble with Democratic Management," Trans-action 3:30-35 (July/Aug. 1966).

Hall, Richard H. "Some Organizational Considerations in the Professional-Organizational Relationship," Administrative Science Quarterly 12:461-78 (1967).

Heller, Frank A. Managerial Decision Making. London: Tavistock, 1971.

Holley, Edward G. "Organization and Administration of Urban University Libraries," College \& Research Libraries 33:175-89 (May 1972).
Kaplan, Louis. "Participation: Some Basic Considerations on the Theme of Academe," College \& Research Libraries 34:235-41 (Sept. 1973).

Kaser, David. "Modernizing the University Library Structure," College \& Research Libraries 31:227-31 (July 1970).

Likert, Rensis. New Patterns of Management. New York: McGraw-Hill, 1961.

Lowin, Aaron. "Participative Decision Making: A Model, Literature Critique and Prescription for Research," Organizational Behavior and Human Performance 3:68-106 (1968).

Lynch, Beverly P. "An Empirical Assessment of Perrow's Technology Construct," Administrative Science Quarterly 19:338-56 (1974).

Lynch, Beverly P. "Organizational Structure and the Academic Library," Illinois Libraries 56:201-6 (1974).

Marchant, Maurice P. "Participative Management as Related to Personnel Development," Library Trends 20:48-59 (1971).

Presthus, Robert V. The Organizational Society. New York: Knopf, 1962.

Schwab, Donald P., and Cummings, Larry L. "Theories of Performance and Satisfaction: A Review," Industrial Relations 9:408-30 (1972).

Strauss, George. "Some Notes on Power Equalization," in Harold J. Leavitt, ed., The Social Science of Organizations, p.41-84. Englewood Cliffs, N.J.: Prentice-Hall, 1963.

Tannenbaum, Arnold S., and others. Hierarchy in Organizations. San Francisco: Jossey-Bass, 1974.

Vroom, Victor H. "A New Look at Managerial Decision Making," Organizational Dynamics 1:66-80 (1973).

Vroom, Victor H. Work and Motivation. New York: Wiley, 1964. 